\title{
The Profile of Adolescent' Moral Intelligence and Practical Solution to Its Improvement Efforts
}

\author{
Hardi Prasetiawan, Muya Barida \\ Universitas Ahmad Dahlan, Yogyakarta
}

\begin{abstract}
High moral quality is needed by adolescent to be success in their personal and educational life. Those who have high morale quality can be considered as morally intelligent Individuals. This study is aimed to collect information about adolescents' moral intelligent by using moral intelligence Instrument that consists of seven aspects, empathy, self control, conscience, respect, kindness, tolerance dan fairness, furthermore, alternative solution is given to improve their moral intelligence. Subject of this study was selected through simple random sampling. Based on the result of the survey, it was found that students in a State Junior high school in Yogyakarta have 69\% moral intelligence percentage. In other words, they have medium moral Intelligence. Adolescents' moral quality develops through continuous process in their life. One of many methods that can be done to improve moral intelligence is guidance and counseling service, in specific, group counseling with self- management technique.
\end{abstract}

Keywords: Adolescents, Moral Intelligence, Self- Management Technique

\section{INTRODUCTION}

Moral becomes the primary issue in human life. Its problems exist since the human exist. Even Muhammad SAW was sent to improve human morality, as it is quoted from his words: "I have only been sent to perfect good moral character. Philosophers such as Socrates, Aristotle, Ibn Ruysd, Al Gazhali, up to Imanuel Kant realize the importance of moral factor in human life (Muthahhari, 2008). In psychological study, Piaget and Lawrence Kohlberg focused their study on discussing children until adults' moral development. Those studies indicate that one of primary base of a nations' welfare and advancement substance is moral.

Someone' morality can be seen from their behavior. Data from Koran Rakyat Merdeka (in Azhar \& Putri, 2009) about the result of National Child Protection Commission' survey explains that, in $200797 \%$ of 4500 adolescents in several big cities in Indonesia have watched porn movies, 93\% of them have kissed their boyfriend or girlfriend. While 62,7\% adolescents in Junior High School level already have sex and 21,2\% Senior High School level students have ever done abortion. According to Taher (2007), this condition does not naturally happen, yet it is caused by their environments which have been contaminated by products with outside values. That fact becomes a sign that this nation is experiencing severe moral decadence, and if it is ignored, the existence of this nation and religion will collapse.

Borba (2008) states that many attempts and methods have been done in order to develop positive moral characters in children (Akhlakul Karimah), starts from social approaches, conflict resolution ability, stress management, self confidence that is told by the teachers, until Howard Garder' idea about multiple Intelligence and Daniel Goleman with his idea about Emotional intelligence, yet moral crisis still continues. Therefore, one of effective solutions is directing children and adolescent' ability to steadily understand about what is right and wrong. This ability can be called as Moral Intelligence

Term 'moral' is adopted from Latin "mos" (plural: mores) which means habit. Yusuf (2008: 132) added that moral, asides from habit, also means a rule, values, or procedures in life. Studies about moral that have been widely known are Freud, Piaget, Kohlberg, Gilligan and Turiel (Çam et. al., 2012).

Bull (in Devine, 2006: 4) suggested that moral is All morality consists of relationships between persons; that its three concerns are therefore, self, others and the relationship between them; and that the heart of morality is therefore respect for persons. Furthermore, Lennick \& Kiel (2008:31) defined Moral intelligence as the mental capacity to determine how universal human principlesshould be applied to our values, goals, and action.

Borba (in Moghadas \& Khalegi, 2013) defined moral intelligence as the capacity to distinguish right from wrong and to act according to a moral certainty in order to provide correct and honorable behavior. This type of intelligence shows the human mental capacity to determine how universal human principles, values and goals related to the actions. Also moral Intelligence represents one's ability to set standards of excellence 
and passion beyond his interests and even in the midst of such topics as the effectiveness of individual reactions.

Clarken (2009) stated that moral intelligence refers to the ability to apply ethical principles to personal goals, values and actions. Moral Intelligence is considered as Individual' ability in understanding what is right out of what is wrong, having strong ethic beliefs, and act or behave for the right and honorable things (Olusola, Ajayi, \& Samson, 2015). Adolescents with high moral intelligence always do good things for themselves, or even other people.

Based on theoretical description about moral intelligence, it can be said that moral intelligence is individual' moral ability that involves emotional and intellectual factor to think, behave, and act based on the society' values which can be applied in life' purposes and actions.

According to Borba (2008: 7-10), there are seven virtues that become the main essence as foundation to act and behave ethically. To describe adolescent' moral intelligence in this study, these virtues become the foundation: 1) Empathy, Ability to feel and understand other people' worries; 2) Conscience, Ability to know and apply how to act correctly; 3) Self Control, Ability to control mind and act in order to resist negative inside or outside encouragement, so they are able to act correctly; 4) Respect, Ability to appreciate other individual and act nicely and politely; 5) Kindness, Ability to show concern to other individual' well-being and feeling; 6) Tolerance, Ability to respect other individual' right and dignity, although they have different faith and behavior; and 7) Fairness, Ability to be open minded and acts honestly and correctly.

Yusuf (2008) revealed that morality concept from childhood until adolescence is dominantly influenced by environment factor, especially family environment, society environment, and school environment. Process of moral concept understanding (right-wrong, good-bad) on children and adolescents is totally different. Children' understanding about moral tends to be heteronomy since they understand that adult' rules is a law, this concept belongs to Piaget, which was then developed by Kohlberg at its pre-conventional level. While for the adolescents, the concept of moral develops to conventional level and post-conventional level. This adolescents' moral character is important and able to develop through moral character development guidance program so that is able to shape adolescents' personality.

This article discusses the result of adolescent' moral intelligence survey at Junior High School level students in Yogyakarta. This article also gives alternative solution in improving moral intelligence practically through group counseling service with self-management technique.

\section{METHODS}

This Study used quantitative approach with descriptive survey method (Lodico, Spaulding, Voegtle, 2010: 199). The subjects of this study are chosen through random sampling technique in a State Junior High School of Yogyakarta (Leedy \& Ormrod, 2005). The collected data was information about moral intelligence level. It was in form of numerical data.

The used instrument to collect the data of this study was moral intelligence scale, which consists of seven aspects namely empathy, conscience, self-control, respect, kindness, tolerance, and fairness. The scale was consists of eighty eight reliable and valid items. Empathy aspect consists of twenty two items (adapted from Davis, 1980), Conscience aspect consists of eight item (adapted from Lerner, 2005), Self-control aspect consists of ten items (adapted from Tangney, Baumeister, \& Boone, 2004), Respect aspect consists of eleven items (adapted from Hendrick \& Hendrick, 2006), Kindness aspect consists of thirteen item (adapted from Comunian, 1998), Tolerance aspect consists of twenty two items (adapted Thomae, Birtel, \&Wittemann, 2016), and fairness aspect consists of two items (ddapted from Bharadwaj, 2014).

The Instrument used 4 level likert scales, namely very suitable, suitable, unsuitable, and very unsuitable. For favorable items, the score for very suitable answer equals to 4, suitable answer equals to 3, Unsuitable equals to 2 , very unsuitable equals to 1 . While for unfavorable items, score 1 is given for very suitable answer, 2 for suitable, 3 for unsuitable, and 4 for very unsuitable. Afterwards, the data analyzed by using descriptive statistic analysis technique which is observed from percentage of total score. Percentage of $76 \%$ $100 \%$ is categorized as high, $56 \%-75 \%$ is categorized as medium, while if the percentage is less than $56 \%$, it is categorized as low.

\section{RESULTS}

\subsection{Empathy Aspect Analysis}

The average percentage of students' empathy is $68 \%$ and it is categorized as Medium. 


\subsection{Self-Control Aspect Analysis}

The average percentage of students' self-control is $66 \%$ and it is categorized as Medium.

\subsection{Conscience Aspect Analysis}

The average percentage of students' conscience is $72 \%$ and it is categorized as Medium.

\subsection{Respect Aspect Analysis}

The average percentage of students' respect is $71 \%$ and it is categorized as Medium.

\subsection{Kindness Aspect Analysis}

The average percentage of students' empathy is $68 \%$ and it is categorized as Medium.

\subsection{Tolerance Aspect Analysis}

The average percentage of students' tolerance is $69 \%$ and it is categorized as Medium.

\subsection{Fairness Aspect Analysis}

The average percentage of students' fairness is $68 \%$ and it is categorized as Medium.

\subsection{Adolescents' Moral Intelligence level Analysis}

The average percentage of students' moral intelligence is $66 \%$ and it is categorized as Medium.

\section{IMPLICATIONS}

Human have different moral reflection and its development and change occurs gradually (Plümer, 2007). Adolescents with medium moral intelligence level need assist when facing their problems since moral intelligence will directly affect them as citizen (Siphai, 2015). Guidance and Counseling services are needed in order to do curative attempt related to personal and social adolescents' problem. There is a guidance and counseling service which is able to be done in solving problem together namely Group Counseling.

One of many abilities that counselors must have is ability to be able to do counseling in group activity. Being seen from the angle of intertwined relationship between counselee and counselors, according to Natawidjaja (2009: 3) group counseling is a guidance technique which is done in form of group. Group guidance and counseling utilizes group atmosphere as treatment and remedial medium or to develop counselee individually. Jacobs \& Harvill (2012: 19) stated that group counseling is better because members need the input from others, plus they learn more from listening than talking. In many instances with teenagers, group counseling is better than individual counseling because teenagers often will talk more readily to other teenagers than with adults. For those stuck in the grief process, groups have been found to be very valuable.

Corey (2012: 4) defined group counseling has preventive as well as remedial aims. Generally, the counseling group has a specific focus, which may be educational, career, social, or personal. Counseling groups are often problem oriented, and the members largely determine their content and aims. Group members typically do not require extensive personality reconstruction, and their concerns generally relate to the developmental tasks of the life span. Group counseling tends to be growth oriented in that the emphasis is on discovering internal resources of strength.

Based on some experts' definition about group counseling above, it can be conclude that a service that is done by counselor to a group of individual who experiencing some problems in order to solve them, so their potential will not be hampered.

Gibson \& Mitchell (2011: 275) propose the term of group counseling refers to routine adjustment or experience development in group scope. Group counseling is aimed to assist counselee overcome their problems through daily self adjustment and self development. 
Group counseling has sequence of process or procedure. Corey (2011:71) defined group process as development steps of a group and characteristic of each step. The followings are process of group counseling: 1) Beginning Stage, 2) Transition Stage, 3) Working Stage, dan 4) Termination Stage. One of many techniques that are able to be applied in group counseling is self management.

Group counseling service is one many guidance and counseling services in school. Group counseling is an attempt given to the students in order to solve their personal and social problems together, so that they can develop dynamic social relation in their group environment. Self management technique can be used in group counseling.

Self Management can be defined as individuals' ability to manage themselves. Nursalim (2013: 149) stated that self management is a process where counselee directs their own behavior through one or more strategies. Counselee should actively move the internal and external variable in order to get the desired changes.

Furthermore, Woolfolk (2009: 409) conveyed that self management is managing our own behavior and being responsible for our own action. In the behavioral theory, behavioral principles are used to change the behavior.

Based on some definition above, it can be concluded that self management is a behavior change strategy which in the process, counselee (adolescent) direct their behavioral change through a technique or therapeutic technique combination.

Self management technique belongs to cognitive behavioral modification and cognitive behaviorism therapy. Woolfolk (2009) said that the root of self management is operant conditioning theory with social cognitive technique. Generally, Self management means technique that makes students include in basic steps in behavior change program. Basic assumption on cognitive behavioral counseling is that the process of group counseling is able to change someone' cognition. It takes important role in self management process and behavioral change that is controlled by internal and external interactions that possibly affect them outside counseling session.

Nursalim (2013) explained that self management consists of self monitoring, stimulus control and positive reinforcement (self reward) Practically, self management has some excellences such as improving individual' understanding about environment and decreasing their addiction to the counselors or others, practical, inexpensive, and easily answered. So in this case, self management technique can improve students or adolescents' moral intelligence.

According to Nursalim (2013: 153), there are three strategies of self management namely Self Monitoring, Stimulus Control and Self Reward. Self monitoring is a process where counselee observes and notes something about themselves and their interactions with environment' situation. Stimulus control is an arrangement or planning of environment' determined conditions that become the reason of why a behavior is done. Stimulus control emphasized the environment rearrangement or modification as particular reason of a certain reaction. Self reward is used to strengthen or improve the desired response (Nursalim 2013: 157-158). The function of self reward is to accelerate the appearance of targeted behavior. Through combination of self monitoring, stimulus control, and self reward, it is expected that adolescents can improve positive moral intelligence.

Self management technique is a strategy of behavioral changing and development that emphasizes the importance of self responsibility and effort in order to change and develop adolescents' behavior. The process of this behavioral change is mostly done by the counselee themselves, not directed by other people (counselor). So in this study it can be said that group counseling model with self management technique can be applied to improve adolescent' moral intelligence.

Group counseling with self management technique focuses on behavioral change and integrates changes that occur between its sessions. In order to improve moral intelligence, identification is needed to find out the level of moral intelligence. Moreover, treatment can't be done just once since evaluation is needed in order to see how far this counseling model can improve adolescents' moral intelligence. Evaluation is done by the counselor together with the counselee to see whether the counseling target is achieved or not.

\section{CONCLUSION}

Moral intelligence is individual' moral ability that involves emotional and intellectual factor to think, behave, and act based on the society' values which can be applied in life' purposes and actions. Moral intelligence consists of seven aspects namely empathy, conscience, self-control, respect, kindness, tolerance, and fairness. Adolescents can develop those aspects start from the first three aspect, and then when the first 
three aspects is done, they can develop the last four which are consist of respect, kindness, tolerance, and fairness.

A set of primary virtue that then is called as moral intelligence can be improved through group counseling with self management technique model Self management technique consist of self monitoring, stimulus control dan self reward. Firstly, Adolescents monitors their mind, feeling, and behavior in daily life. Then they control their mind, feeling and behavior to the positive way. If they can positively directing themselves to the positive context, they may give themselves a reward. Through self reward, they will be encouraged to improve their moral intelligence.

\section{REFERENCE}

Azhar, MH. (2009). Kecerdasan Moral Pada Remaja Yang Mengalami Deviasi Mothering. Jurnal Psikologi, 2 (2).

Bharadwaj, P. (2016). Fairness and Social Justice: Distinct Moralities. Masters These, 337.

Borba, M. (2008). Membangun Kecerdasan Moral. Jakarta: Gramedia Pustaka.

Çam, Z., Çavdar, D., Çok, F., \& Seydooğullari, S. (2012). Classical And Contemporary Approaches For Moral Development. Educational Sciences: Theory \& Practice, 12 (2): 1222-1225.

Clarken, R.H (2009). Moral Intelligence in Schools. Online Submission. Paper presented at the Annual Meeting of the Michigan Academy of Sciences, Arts and Letters (Detroit, MI, Mar 20, 2009).

Comunian, A.L. (1998). The Kindness Scale. Psychological Reports, 83: 1351-1361.

Corey, G. (2011). Teori dan Praktek dari Konseling dan Psikoterapi Edisi Ke 4. Semarang: IKIP Semarang Press.

Corey, G. (2012). Theory \& Practice of Group Counseling Eighth Edition. Pacific Groove. California: Brooks/Cole.

Davis, M.H. (1980). A Multidimensional Approach to Individual Differences in Empathy. JSAS Catalog of Selected Documents in Psychology, 10 (85).

Devine, S. (2006). What is Moral Education. Nourthampton: Susan Devine.

Gibson, R. \& Mitchell M. (2011). Bimbingan \& Konseling. Cetakan I. Yogyakarta: Pustaka Pelajar.

Hendrick, S. S., \& Hendrick, C. (2006). Measuring Respect in Close Relationships. Journal of Social and Personal Relationships, 23: 881-899.

Jacobs, M. \& Harvill. (2012). Group Counseling Strategies And Skills Seventh Edition. West Virginia University America: Brooks/Cole.

Leedy, P.D. \& Ormrod, J.E. (2005). Practical Research: Planning and Design 6th edition. Amerika Serikat: Pearson Education.

Lennick, D. \& Kiel, F. (2008). Moral Intelligence, Enhancing Business Perfomance \& Leadership Success. New Jersey: Pearson Education Inc.

Lerner, R.M. (2005). Social Conscience Scale. Dikses https://cyfar.org/sites/default/files/PsychometricsFiles/Social \%20Conscience\%20(middle\%20school)_1_0.pdf

Lodico, M.G., Spaulding, D.T., \& Voegtle, K.H. (2010). Methods in Educational Research: From Theory to

Practice second edition. United States of America: John Wiley \& Sons, Inc.

Moghadas, M. \& Khaleghi, M. (2013). Investigate of Relationship Between Moral Intelligence and Distress Tolerance In Isfahan Staff. International Journal of Research In Social Sciences, 2 (2).

Muthahhari, M. (2008). Falfasatul Akhlaq. (Terjemahan) Quantum Akhlak. Yogyakarta: Arti.

Natawidjaja, R. (2009). Konseling Kelompok Konsep Dasar \& Pendekatan. Cetakan I. Bandung: Rizqi Press.

Nursalim, M. (2013). Strategi \& Intervensi Konseling. Cetakan I. Akademia Permata. Jakarta: Indeks.

Olusola, O.I., Ajayi, Samson, O. (2015). Moral Intelligence: An Antidote to Examination Malpractices in Nigerian Schools. Universal Journal of Educational Research, 3 (1): 32-38.

Plümer, S.L. (2007). Education in Values and Moral Education in Vocational Colleges. European Journal Of Vocational Training, 41 (2): 103-115.

Siphai, S. (2015). Influences of Moral, Emotional and Adversity Quotient on Good Citizenship of Rajabhat University's Students in the Northeast of Thailand. Universal Journal of Educational Research, 3 (2): 32-38.

Taher, T. (2007). Membenahi Moral Bangsa, Meneladani Akhlak Rasul.

Tangney, J.P., Baumeister, R.F., \& Boone, A.L. (2014). High Self-Control Predicts Good Adjusment, Less Pathology, Better Grades, and Interpersonal Success. Journal of Personality, 271-324.

Thomae, M., Birtel, M.D., \& Wittemann, J. (2016). The Interpersonal Tolerance Scale (IPTS): Scale Development and Validation. Paper Presented at the 2016 Annual Meeting of the International Society of Political Psychology, Warsaw, Poland, $13^{\text {th }}-16^{\text {th }}$ July 2016.

Woolfolk, A. (2009). Educational Psychology Active Learning Edition Tenth Edition. Cetakan I. Yogyakarta: Pustaka Pelajar

Yusuf, S. (2008). Psikologi Perkembangan Anak \& Remaja. Bandung: Rosda. 